\title{
METHANE PRODUCTION POTENTIAL OF AZOLLA UNDER DIFFERENT RATIOS OF C/N, CHEMICAL AND THERMAL PRE-TREATMENT
}

\author{
Majid FARDMANESH, Razieh POURDARBANI*, Bahman NAJAFI \\ University of Mohaghegh Ardabili, Ardabil, Iran
}

\begin{abstract}
Azolla algae currently represent a major threat to the environment and rice cultivation fields. Various studies have shown that one of the practical solutions is to turn this threat into an opportunity for biomass energy production. This research investigates the production potential of methane in Azolla. Test was conducted in a completely randomized design (CRD) with Mini Tap software. Three different C/N ratios, 30, 34 and 38, two levels of thermal pre-treatment (raw and steamed Azolla) and two levels of chemical pre-treatment $(\mathrm{NaOH} 0 \%$ and $9 \%)$ were used and effects of each case on the methane production rate was studied. The highest amount of methane $\left(247.7 \mathrm{ml} \cdot \mathrm{g}^{-1}\right.$ vs $)$ was produced at $\mathrm{C} / \mathrm{N}$ ratio of 30 with application of $\mathrm{NaOH}(9 \%)$ and no thermal pre-treatment (raw Azolla). ANOVA analysis showed that interactions of the effective variables were significant, but the trend was not incremental or decreasing; therefore, ANFIS and stepwise regression modelling were used. The results showed that the ANFIS model provides more accurate mapping between the empirical and predicted values than the regression model. Furthermore, among examined models (triangular; trapezoidal; Gaussian; bell-shaped models), the best model for methane production prediction was Gaussian linear membership function $\left(R^{2}=0.997\right.$ and $\left.\varepsilon(\%)=0.32\right)$. According to the regression model, the thermal-chemical factor is the most efficient in prediction of the model $(b=35.6)$.
\end{abstract}

Keywords: Azolla algae; ANFIS; C/N ratio; regression model

Azolla is a floating aquatic fern that grows rapidly in stagnant waters and ponds and covers the water surface. This coating is very dangerous for aquatic organisms by creating a layer at the water level, which prevents the sunlight from reaching other herbaceous grasses, thus preventing their growth. Transfer of Azolla from the Philippines to Iran (Gilan province) had unpleasant consequences over the last few years. It is accessible throughout the year, and although this plant is not native to Iran, it adapted and rapidly expands. Currently, the plant is a major threat to the northern region of Iran, and considerable costs are annually spent on collection of this algae from the environment. However, after its collection, it can be put to some use. Anaerobic digestion of Azolla with cow dung is an alternative for $\mathrm{C} / \mathrm{N}$ ratio modification in order to increase the gas production - Azolla fixes atmospheric $\mathrm{N}$, thus reducing the necessary amount of cow dung for biogas production (Paudel, 2009). Wilkie (2000) reported that anaerobic digestion is a natural process converting the biomass to energy. Yadava and Hesse (1981) declared that biogas consists of $50-70 \% \mathrm{CH}_{4} ; 30-40 \% \mathrm{Co}_{2} ; 5-10 \%$ $\mathrm{H}_{2} ; 1-2 \% \mathrm{~N}$ and $\mathrm{H}_{2} \mathrm{~S}$. Based on the reports, biomass can be considered an energy source with potential to satisfy $14 \%$ of global energy demand. In developed countries, this share is estimated to be $40-50 \%$ (Anonymous, 2013). Biomass utilization can reduce the greenhouse gas emissions, as it can balance the production and consumption of carbon dioxide. From all alternative sources, biomass represents the main source for renewable energy production (Adelard et al., 2015). Utilization of biogas technology at microand macro-scales has been considered as a promising approach, especially in development planning, organic waste management in urban and rural areas (Abdeshahian et al., 2016; Kažimírová et al., 2018). Research on methane production from Azolla is scarce; Das et al. (1994) studied the biogas production from Azolla - authors mixed Azolla and cow dung in different proportions, namely $1: 0.2,1: 0.4$ and $1: 0.6$. They observed that the ratio of $1: 0.4$ showed the highest biogas production. Roy et al. (2016) also found that the amount of produced hydrogen increases when the Azolla is cultivated in a controlled environment with incomplete vacuum and injection of either argon gas or rich carbon dioxide into the cultivation bed. Shilpakar and Shilpakar (2009) reported that, with high C/N ratio, nitrogen was rapidly consumed by methanogens in order to meet the protein requirements, which no longer reacted with leftover $\mathrm{C}$ content, resulting in a low gas production. On the other hand, with low $\mathrm{C} / \mathrm{N}$ ratio, $\mathrm{N}$ was accumulated in the form of ammonia, which increased $\mathrm{pH}$. Tasnim et al. (2017) investigated the biogas production by means of an anaerobic digestion of cow manure with kitchen waste and hyacinths. Basri et al. (2010) studied the biogas production from palm leaves. Phetyima et al. (2015) examined the biogas production from vegetable waste with dog and cattle manure.

Contact address: Razieh Pourdarbani, University of Mohaghegh Ardabili, Faculty of Agriculture \& Natural Sciences, Department of Biosystem Engineering, Ardabil, Iran, 56199-11367, 00989143162785, e-mail: r_pourdarbani@uma.ac.ir 
All in all, Azolla is considered a threat to Anzali wetland due to the aforementioned disadvantages. One of the practical solutions is to turn this threat into an economically viable opportunity, which would be possible with the construction of biogas production reservoirs. Therefore, this research attempts to identify the variables affecting the production potential of methane from Azolla using ANFIS and regression modelling.

\section{Material and methods}

\section{Methane production method}

Firstly, Azolla was collected from Anzali Lagoon. Subsequently, dung was collected from the dairy; in order to enrich it, an amount of water equivalent to the cow dung weight ( $1 \mathrm{~kg}$ ) was added to it. Before mixing Azolla and cow dung, samples of both were sent to the laboratory in order to determine the $\mathrm{C} / \mathrm{N}$ ratio: $73 / 26$ for cow dung and $65 / 65$ for Azolla. There were examined two levels of chemical pretreatment (with $\mathrm{NaOH}$ content of $9 \%$ and $0 \%$ ); two levels of thermal pre-treatment (steamed Azolla for $60 \mathrm{~min}$, and raw Azolla without thermal pre-treatment) and three $\mathrm{C} / \mathrm{N}$ ratios of $30,34,38$.
By determining the amounts of cow dung, Azolla and water (as shown in Table 1), the bottles were loaded. In order to establish the constant temperature of $37^{\circ} \mathrm{C}$, these were placed in a hot water bath (under the conditions of the mesophilic bacteria) and the gas production stage began. For the purposes of the produced gas transfer, a pipe was provided on the doors of the digesters, transferring the produced gas to the bottles outside the heated bath. The useful gas extracted from biogas with high thermal value is methane. Therefore, the method of positive displacement of liquids (water) was used to determine the methane in the biogas. It was examined twice a day and the quantities of gas produced from each digestion were measured. Each digestion lasted for 90 days.

\section{Data analysis method}

The model was based on 4 input factors, including time of thermal pre-treatment (steamed Azolla; raw Azolla), chemical pre-treatment $(\mathrm{NaOH} 9 \% ; 0 \%), \mathrm{C} / \mathrm{N}$ ratio $(33 ; 34$; 38) and number of days (90 days). Four types of membership functions (triangular, trapezoidal, Gaussian, and bell-shaped functions) were considered as membership functions for representing the inputs.

Hybrid optimization method was used for network learning. The number of rules created by the network was 36 . Due to the high number of rules created, only a few of

Table 1 Ratios for each biogas production digester

\begin{tabular}{|l||c|c|c|c|c|c|c|c|}
\hline Sample & Water & Azolla & Cow dung & $\mathbf{C / N}$ & NaOH 9\% & NaOH 0\% & Steamed Azolla & Raw Azolla \\
\hline $\mathbf{1}$ & $1,107.5$ & 59.1 & 333 & 30 & & $*$ & & $*$ \\
\hline $\mathbf{2}$ & $1,215.1$ & 118.2 & 166.6 & 34 & & $*$ & $*$ \\
\hline $\mathbf{3}$ & $1,322.7$ & 177.3 & 0 & 38 & & $*$ & $*$ \\
\hline $\mathbf{4}$ & $1,107.5$ & 59.1 & 333 & 30 & $*$ & & $*$ \\
\hline $\mathbf{5}$ & $1,215.1$ & 118.3 & 166.6 & 34 & $*$ & & $*$ \\
\hline $\mathbf{6}$ & $1,322.7$ & 177.3 & 0 & 38 & $*$ & & $*$ & $*$ \\
\hline $\mathbf{7}$ & 824.3 & 342.7 & 333 & 30 & & $*$ & $*$ & $*$ \\
\hline $\mathbf{8}$ & 652.4 & 680.8 & 166.6 & 34 & & $*$ & $*$ & $*$ \\
\hline $\mathbf{9}$ & 478.7 & $1,021.2$ & 0 & 38 & & $*$ & $*$ & $*$ \\
\hline $\mathbf{1 0}$ & 824.3 & 342.7 & 333 & 30 & $*$ & & $*$ & $*$ \\
\hline $\mathbf{1 1}$ & 652.4 & 680.8 & 166.6 & 34 & $*$ & & $*$ & $*$ \\
\hline $\mathbf{1 2}$ & 478.7 & $1,021.2$ & 0 & 38 & $*$ & & $*$ & $*$ \\
\hline
\end{tabular}

Table 2 Part of the rules for the methane production model

\begin{tabular}{|c|c|c|c|c|c|}
\hline \multirow[t]{2}{*}{ Rules } & \multicolumn{4}{|c|}{ Input variables } & \multirow[t]{2}{*}{ Linear output function (methane) } \\
\hline & thermal & NAOH & Day & $\mathbf{C} / \mathbf{N}$ & \\
\hline 6 & $\mathrm{~S}$ & $\mathrm{~L}$ & M & $\mathrm{H}$ & methane $=2,392 \mathrm{M}+0 \mathrm{~N}-15,060 \mathrm{D}+18,180+478.4$ \\
\hline 12 & S & $\mathrm{H}$ & L & $\mathrm{H}$ & methane $=2.957 \mathrm{M}+5.322 \mathrm{~N}-1,140 \mathrm{D}+22.47 \mathrm{C}+0.5913$ \\
\hline 18 & $\mathrm{~S}$ & $\mathrm{H}$ & $\mathrm{H}$ & $\mathrm{H}$ & methane $=352.8 \mathrm{M}+635.1 \mathrm{~N}-1,156 \mathrm{D}+2,681 \mathrm{C}+70.56$ \\
\hline 24 & $\mathrm{R}$ & L & M & $\mathrm{H}$ & methane $=34,230 \mathrm{M}+0 \mathrm{~N}-67,810 \mathrm{D}+65,030 \mathrm{C}+1,711$ \\
\hline 30 & $\mathrm{R}$ & $\mathrm{H}$ & L & $\mathrm{H}$ & methane $=234.9 \mathrm{M}+105.7 \mathrm{~N}-23,160 \mathrm{D}+446.4 \mathrm{C}+11.75$ \\
\hline 36 & $\mathrm{R}$ & $\mathrm{H}$ & $\mathrm{H}$ & $\mathrm{H}$ & methane $=22,160 \mathrm{M}+9,971 \mathrm{~N}-23,130 \mathrm{D}+42,100 \mathrm{C}+1,108$ \\
\hline
\end{tabular}


them are presented in Table 2 in order to better understand ANFIS modelling. These rules are based on a Sugen-TangSugen-Kang fuzzy system or TSK. In this system, the rules of if-then are fuzzy, but the result is non-phase and linear combination of input variables. The space of all inputs is divided into two parts, the low region representing the membership function $L$ and the greater region representing the membership function $\mathrm{H}$.

$$
\begin{gathered}
\varepsilon=\frac{100}{N} \sum_{i=1}^{N} \frac{Y_{\text {measured }}-Y_{\text {predicted }}}{Y_{\text {measured }}} \\
R^{2}=\frac{\sum_{i=1}^{N}\left(Y_{\text {measured }}-Y_{\text {predicted }}\right)^{2}}{\sum_{i=1}^{N}\left(Y_{\text {measured }}-Y_{\text {predicted }}\right)^{2}}
\end{gathered}
$$

To evaluate the ability of developed models, two statistical measures of relative error $(\varepsilon)$ and coefficient of determination $\left(R^{2}\right)$ were used, which are given by the following equations (Carman, 2008):

Models based on stepwise linear regression in SPSS software were developed to obtain more information on the effects of each input variable on methane production.

\section{Material and methods}

Considering the samples with $\mathrm{C} / \mathrm{N}$ ratio of $30(1,4,7$ and 10) methane production was low since the first days until the $20^{\text {th }}$ day; however, it began to rise since the $20^{\text {th }}$ day onwards. At the start of production, raw Azolla pre-treated with $\mathrm{NaOH}(0 \%)$ showed higher production increase, but eventually, raw Azolla pre-treated with $\mathrm{NaOH}$ (9\%) showed greater methane production. In fact, chemical pre-treatment accelerates degradation of Azolla lignin and hard substances by destroying the material structure and increases the availability of microorganisms for gaining high production (Zhang et al., 2013). Chemical pre-treatment can manage $\mathrm{pH}$, prevent excessive acidification of digestion by degradation of hard tissues before the hydrolysis and acidification step, and cause the biogas production to be higher in the first peak in contrast to control treatment (Janke et al., 2016).

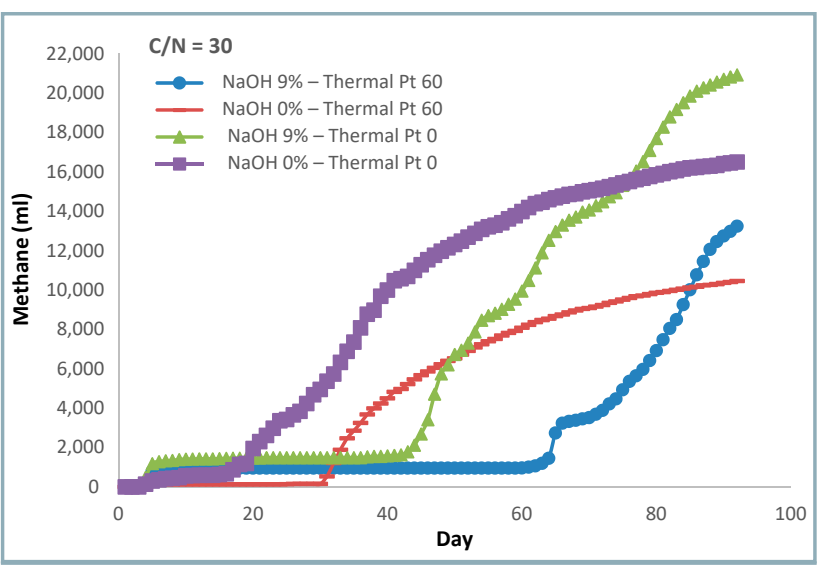

Fig. 1 Cumulative methane production rate of samples 1, 4, 7 and 10 with $\mathrm{C} / \mathrm{N}$ ratio of 30
Fig. 2 demonstrates that, although steamed Azolla started production of methane faster than raw Azolla, higher methane production was observed in raw Azolla. Furthermore, by addition of $\mathrm{NaOH}(9 \%)$, methane bacteria can be active from the beginning in an alkaline environment, since they feed on acetic acid, and microorganisms must be first activated in the acidic environment. Conversion of conditions should be performed in such a manner that the micro-nutrient bed provides the activity field for methane microorganisms. Process of these chain transitions causes methane production to be delayed or start early. In relation to the $\mathrm{C} / \mathrm{N}$ ratio of 30 , this situation is most pronounced. Regarding $\mathrm{C} / \mathrm{N}$ ratios of 34 and 38, the higher the carbon-nitrogen ratio, the faster the acidic environment neutralization of these conditions; this is the reason why $\mathrm{C} / \mathrm{N}$ ratio of 30 showed the highest production (Shilpakar and Shilpakar, 2009).

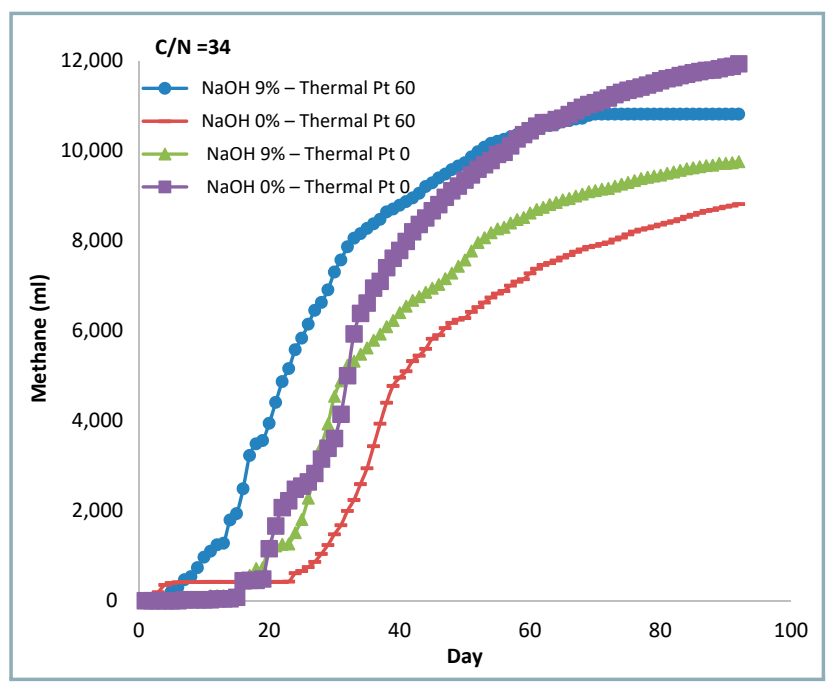

Fig. 2 Cumulative methane production rate of samples 2, 5, 8 and 11 with $\mathrm{C} / \mathrm{N}$ ratio of 34

Fig. 3 depicts how raw Azolla showed higher methane production in comparison to steamed samples. As it was already mentioned, it was expected that chemical pretreatment will show greater effect on methane production, but it was neutralized by the environment being more acidic due to high $\mathrm{C} / \mathrm{N}$ ratio.

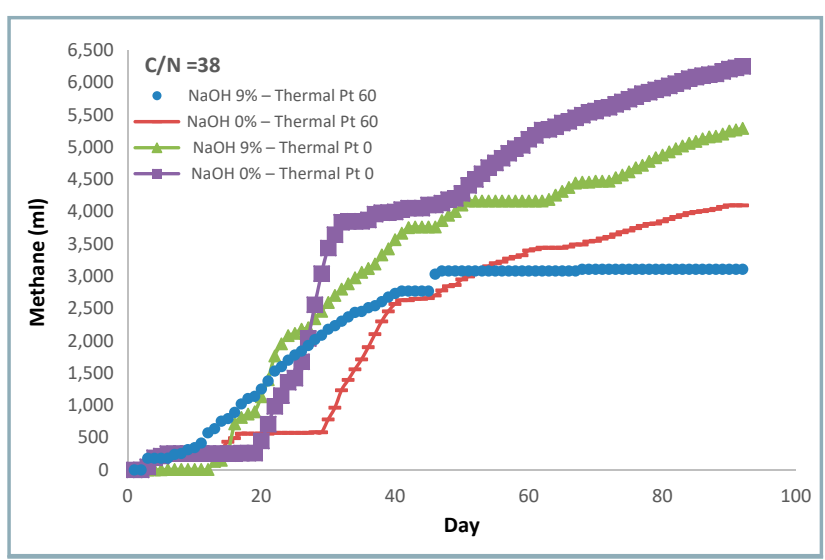

Fig. 3 Cumulative methane production rate of samples 3, 6, 9 and 12 with $\mathrm{C} / \mathrm{N}$ ratio of 38 

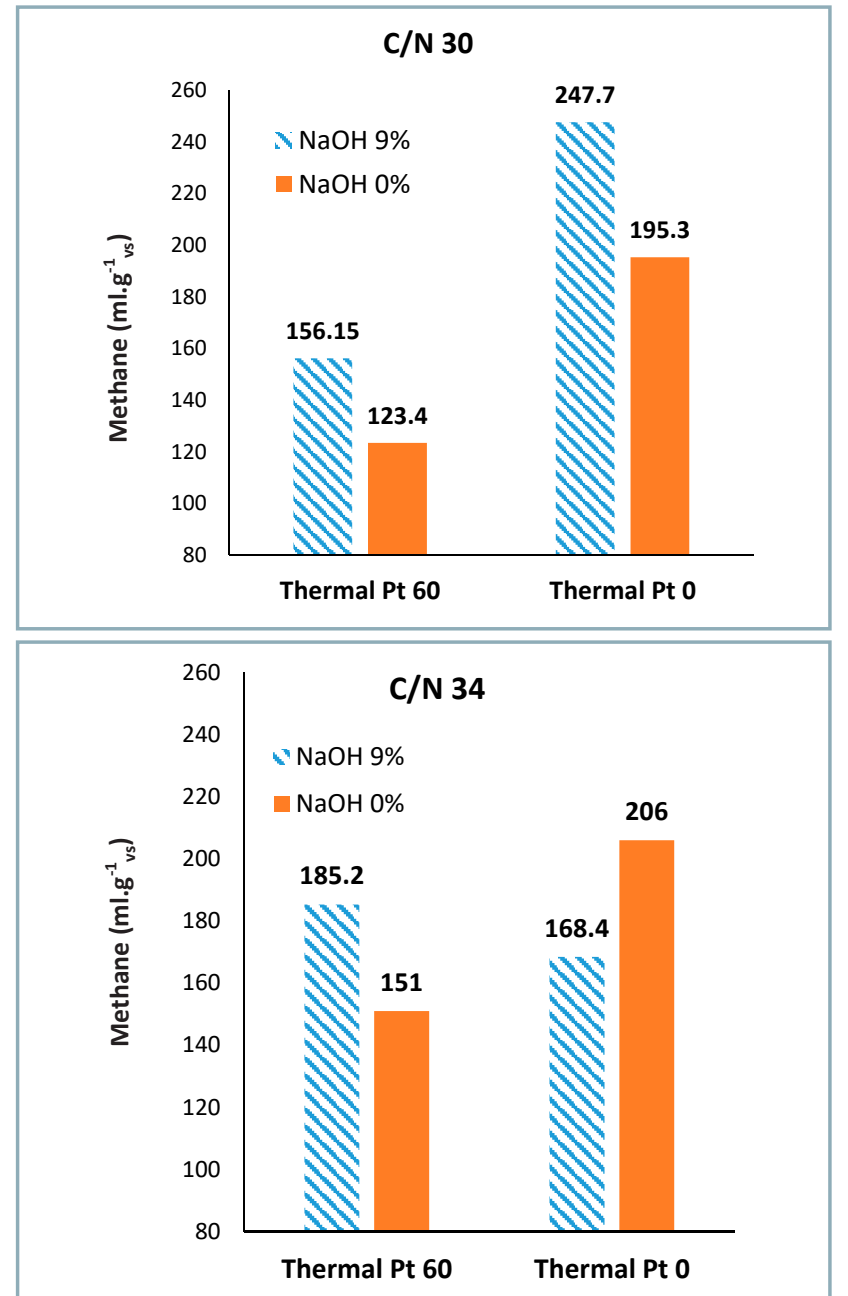

Fig. 4A Cumulative methane production by different samples

The effects of chemical pre-treatment, thermal pretreatment and $\mathrm{C} / \mathrm{N}$ ratios on methane production were analysed by means of Minitab software. The results of methane production are presented in Fig. 4 and Table 3. According to Fig. 4, it was observed that the highest methane production level $\left(247.7 \mathrm{ml} \cdot \mathrm{g}^{-1}{ }_{\text {vs }}\right)$ was obtained for raw Azolla with $\mathrm{C} / \mathrm{N}$ ratio and no thermal pre-treatment (raw

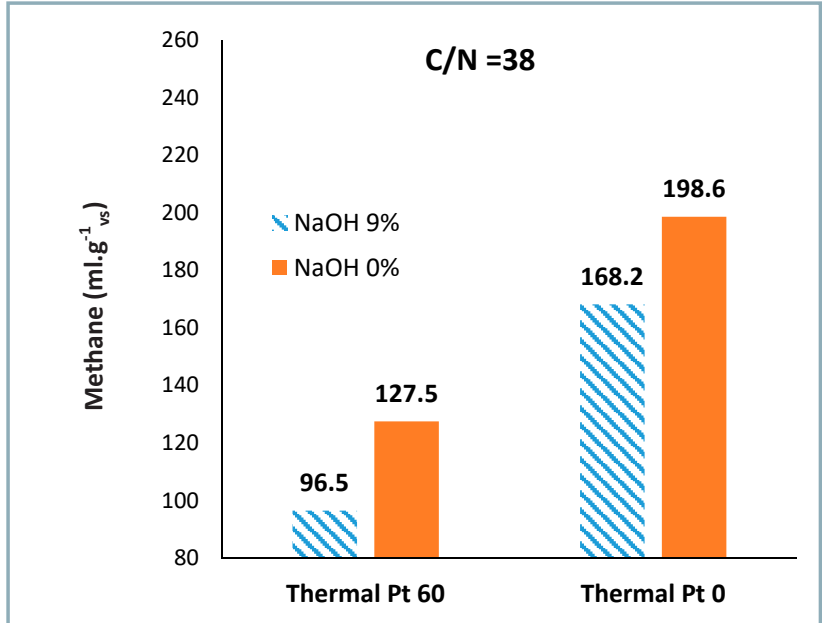

Fig. 4B Cumulative methane production by different samples

Azolla). Moreover, the lowest production rate was showed by steamed Azolla with $\mathrm{C} / \mathrm{N}$ ratio of 38 and $\mathrm{NaOH}(9 \%)$ application. Based on Table 3, there is a significant difference between methane production of raw and steamed samples. Furthermore, there is a significant difference between the methane production of samples with application of $\mathrm{NaOH}$ (9\%) and without it ( $\mathrm{NaOH} 0 \%)$. Considering the significant differences at $5 \%$ level for different $\mathrm{C} / \mathrm{N}$ ratios, there is a difference between methane production of samples with $\mathrm{C} / \mathrm{N}$ ratios of 30 and 34,38 . What is more, interactions between $\mathrm{C} / \mathrm{N}$ ratio and thermal pre-treatment; $\mathrm{C} / \mathrm{N}$ ratio and chemical pre-treatment; as well as thermal pre-treatment and chemical pre-treatment, are also significant. This implies that there is no clear trend between the main effects. As it can be seen in Fig. 4, both raw and steamed samples with $\mathrm{C} / \mathrm{N}$ ratio of 30 pre-treated by $\mathrm{NaOH}(9 \%)$ showed decreasing methane production, however, this trend is completely reversed for samples with $\mathrm{C} / \mathrm{N}$ ratio of 38 . Therefore, it is not possible to identify the effective parameter on the methane production prediction by means of Anova analysis method.

To predict each of the output variables, 4 different models were developed. Table 4 presents the structural parameters of the models with their statistical criteria in order to evaluate their performance. According to the

Table 3 Statistical results of Anova for methane production

\begin{tabular}{|l|c|c|c|c|c|}
\hline Source & Type III sum of squares & df & Mean square & F & Sig. \\
\hline Thermal Pt (TPt) & $29,628.507$ & 1 & $29,628.507$ & $214,986.714$ & $.000^{*}$ \\
\hline Chemical & 114.640 & 1 & 114.640 & 831.836 & $.000^{*}$ \\
\hline CN & $7,941.973$ & 2 & $3,970.986$ & $28,813.781$ & $.000^{*}$ \\
\hline TPt * chemical & 657.495 & 1 & 657.495 & $4,770.834$ & $.000^{*}$ \\
\hline TPt * CN & $6,781.132$ & 2 & $3,390.566$ & $24,602.207$ & $.000^{*}$ \\
\hline Chemical * CN & $8,168.106$ & 2 & $4,084.053$ & $29,634.199$ & $.000^{*}$ \\
\hline TPt * chemical * CN & $3,484.213$ & 2 & $1,742.106$ & $12,640.856$ & $.000^{*}$ \\
\hline Error & 3.308 & 24 & .138 & & \\
\hline Total & $1,081,334.961$ & 36 & & & \\
\hline Corrected total & $56,779.373$ & 35 & & & \\
\hline
\end{tabular}


Table 4 Structure characteristics of developed ANFIS architectures for methane production prediction

\begin{tabular}{|l||c|c|c|c|c|c|c|}
\hline \multirow{2}{*}{ Model } & \multicolumn{2}{|c|}{ Type of MF } & \multicolumn{2}{c|}{ Number of MF } & Optimization & \multicolumn{2}{|c|}{ Test } \\
\cline { 2 - 8 } & input & output & input & epoch & method & $\boldsymbol{\varepsilon}(\%)$ & $\boldsymbol{R}^{\mathbf{2}}$ \\
\hline \multirow{2}{*}{ Grid partition } & trimf & Linear & 2233 & 20 & hybrid & 2.12 & 0.9959 \\
\hline Grid partition & gaussmf & Linear & 2233 & 20 & hybrid & 1.32 & 0.9972 \\
\hline Grid partition & trapmf & Linear & 2233 & 20 & hybrid & 1.19. & 0.9957 \\
\hline Grid partition & gbellmf & Linear & 2233 & 20 & hybrid & 1.18 & 0.9967 \\
\hline
\end{tabular}

Table 5 Results of multiple regression analysis for methane production effective parameters

\begin{tabular}{|c|c|c|c|c|}
\hline \multirow[t]{2}{*}{ Model } & Unstandardized coefficients & Standardized coefficients & & \\
\hline & B & B & $t$ & sig \\
\hline Constant & $-9,040$ & 3,303 & -2.74 & $0.006 \mathrm{~ns}$ \\
\hline Thermal pre-treatment (TPt) & 256 & 227 & 1.13 & $0.259 \mathrm{~ns}$ \\
\hline NAOH & 144 & 519 & 0.28 & $0.782 \mathrm{~ns}$ \\
\hline Day & 428.1 & 61.7 & 6.94 & $0.000^{*}$ \\
\hline $\mathrm{C} / \mathrm{N}$ & 233.4 & 96.7 & 2.41 & $0.016^{*}$ \\
\hline TPt*NAOH & -92.9 & 35.6 & -2.61 & $0.009^{*}$ \\
\hline TPt*day & 16.38 & 4.23 & 3.87 & $0.000^{*}$ \\
\hline $\mathrm{TPt}^{*} \mathrm{C} / \mathrm{N}$ & -6.57 & 6.63 & -0.99 & $0.322 \mathrm{~ns}$ \\
\hline $\mathrm{NAOH}^{*}$ day & -28.28 & 9.69 & -2.92 & $0.004^{*}$ \\
\hline $\mathrm{NAOH}^{*} \mathrm{C} / \mathrm{N}$ & 1.8 & 15.2 & 0.12 & $0.906 \mathrm{~ns}$ \\
\hline Day*C/N & -9.90 & 1.81 & -5.48 & $0.000^{*}$ \\
\hline $\mathrm{TPt}^{*} \mathrm{NAOH}^{*}$ day & 2.448 & 0.665 & 3.68 & $0.000^{*}$ \\
\hline $\mathrm{TPt}^{*} \mathrm{NAOH}^{*} \mathrm{C} / \mathrm{N}$ & 2.28 & 1.04 & 2.19 & $0.029 *$ \\
\hline TPt*day*C/N & -0.391 & 0.124 & -3.15 & $0.002^{*}$ \\
\hline $\mathrm{NAOH}^{*}$ day*C/N & 0.752 & 0.284 & 2.65 & $0.008^{*}$ \\
\hline TPt*NAOH*day*C/N & -0.0690 & 0.0195 & -3.54 & $0.000^{*}$ \\
\hline
\end{tabular}

results presented, all models have high ability $\left(R^{2} \geq 0.99\right.$ and $\varepsilon(\%) \leq 2$ ) of prediction. The best model for methane production prediction is a model that uses the Gaussian linear membership function $\left(R^{2}=0.997\right.$ and $\left.\varepsilon(\%)=0.32\right)$.
The ANFIS model does not provide a specific relationship for modelling the output variable. In contrast, the regression model directly deals with the impact of each factor and attempts to present a model that clearly identifies the

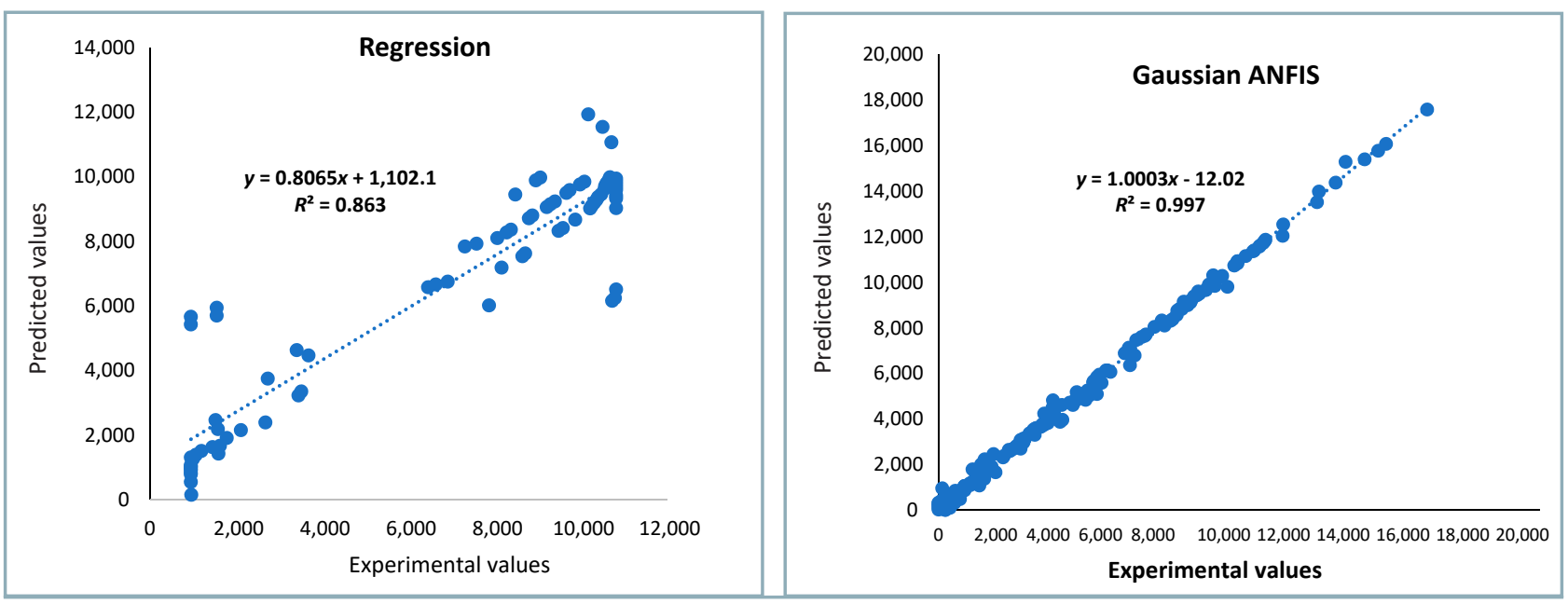

Fig. 5 Experimental and predicted methane production by ANFIS and regression models 


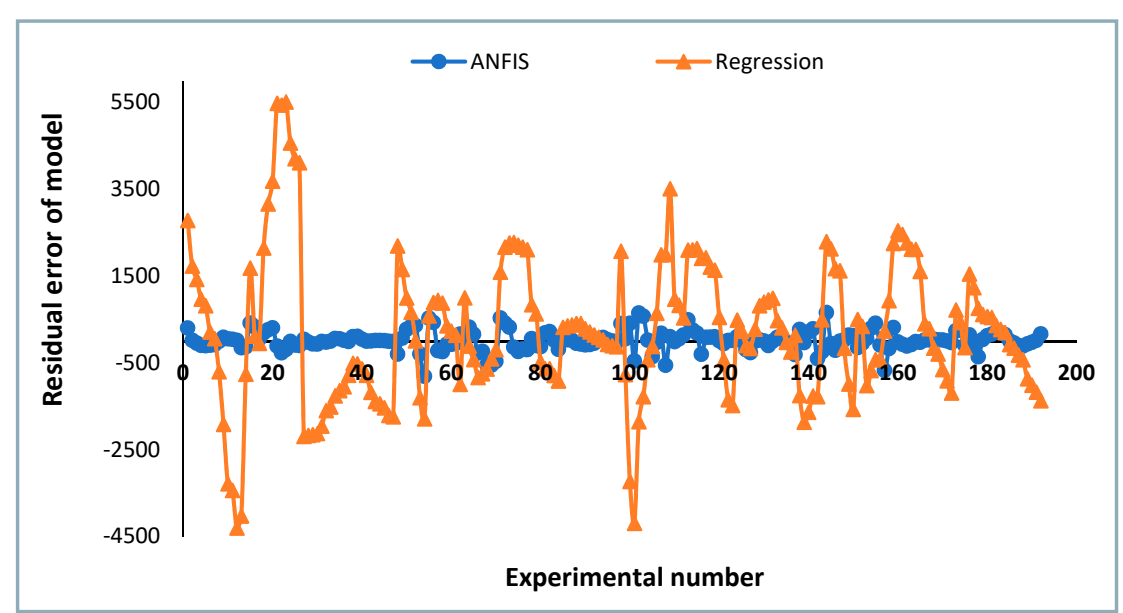

Fig. 6 Variance of the observed values with the values predicted by ANFIS and regression models

significance and effect of each factor. For this purpose, Table 5 presents the statistical characteristics of the methane production prediction by stepwise regression model.

Regarding the results of the regression model presented in Table 5, it was observed that there is no specific trend between the $\mathrm{C} / \mathrm{N}-\mathrm{TPt}$ and $\mathrm{C} / \mathrm{N}$ $\mathrm{NaOH}$ variables; for this reason, these two variables cannot be effective in model prediction. However, multiple effects are significant between the other variables and therefore, considering the beta coefficients contained in the table, TPt $-\mathrm{NaOH}$ factor is more effective in predicting the model $(b=35.6)$.

Fig. 5 shows the mapping between the experimental and predicted methane productions by the ANFIS and stepwise regression models. As it can be seen, the ANFIS model provides a more accurate mapping between experimental and predicted values in contrast to the regression model.

Fig. 6 shows the deviation of each model from the target value. The zero value of deviation is related to the target value. The blue line indicates the deviations associated with the output of the ANFIS; the red line implies the deviations associated with the output of the regression model. Fig. 6 clearly indicates that the ANFIS output shows a minimum deviation from the target value and the highest performance for predicting the model.

\section{References}

ABDESHAHIAN, P. - LIM, J. S. - HASHIM, H. - LEE, C. T. 2016. Potential of biogas production from farm animal waste in Malaysia. In Renewable and Sustainable Energy Reviews, vol. 60, pp. 714-723.
ANONYMOUS. 2013. World Energy Council. London.

BASRI, M. F. - YACOB, S. - HASSAN, M. A. SHIRI, Y. - WAKISAKA, M. - ZAKARIA, M. R. 2010. Improved biogas production from palm oil mill effluent by a scaled down anaerobic treatment process. In World Journal of Microbiology and Biotechnology, vol. 26, pp. 505-514.

CARMAN, K. 2008. Prediction of soil compaction under pneumatic tires a using fuzzy logic approach. In Journal of Terramechanics, vol. 45, pp. 103-107.

DAS, D. - SIKDAR, K. - CHETTERJEE, A. K. 1994. Potential of Azolla pinnata as biogas generator and as a fish feed. In Indian Journal of Environmental Health, vol. 36, pp. 186-191.

JANKE, R. - KONG, J. - BRABERG, H. CANTIN, G. - YATES, J. R. - KROGAN, N. J. HEYER, W. D. 2016. Nonsense-mediated decay regulates key components of homologous recombination. In Nucleic Acids Research, vol. 44, no. 11, pp. 5218-30. KAŽIMÍROVÁ, V. - GADUŠ, J. - GIERTL, T. 2018. Verification of suitability of substrate composition for production and quality of biogas. In Acta Technologica Agriculturae, vol. 21, no. 3, pp. 118-121.

PAUDEL, B. 2009. Suitability of Azolla for biogas slurry enrichment. Thesis in M.S., Kerala Agricultural University, Kerala, India. PHETYIMA, N. - WANTHONGA, T. KANNIKAA, P. - SUPNGAMA, A. 2015. Biogas production from vegetable waste by using dog and cattle manure. In Energy Procedia, vol. 49, pp. 436-441.

ROY, D. C. - PAKHIRA, M. C. - BERA, S. 2016. A review on biology, cultivation and utilization of Azolla. In Advances in Life Sciences, vol. 5, no. 1, pp. 11-15.

SHILPAKAR, P. - SHILPAKAR, D. 2009. Nutrition of rice through Azolla organic material. In Indian Journal of Agronomy, vol. 42, no. 4, pp. 626-633.

TASNIM, F. - AKHTAR, S. - CHOWDHURY, A. R. 2017. Biogas production from anaerobic co-digestion of cow manure with kitchen waste and Water Hyacinth. In Renewable Energy, vol. 109, pp. 434-439.

WILKIE, A. C. 2000. Reducing dairy manure odor and producing energy. In Biocycle, vol. 41, no. 9, pp. 48-57.

ADELARD, L. - POULSEN, T. G. - RAKOTONIA, V. 2015. Biogas and methane yield in response to co- and separate digestion of biomass wastes. In Waste Management and Research, vol. 33, pp. 55-62.
YADAVA, L. S. - HESSE, R. P. 1981. The development and use of biogas technology in rural area of Asia. Improving soil fertility through organic recycling. FAO project RAS/75/004, no. 10.

ZHANG, J. - ZHANG, M. - SHAN, S. - WANG, M. 2013. Effect of biogas slurry application on grain yield. In Journal of AgroEnvironmental Science, vol. 28, no. 10, pp. 2005-2009. 